\title{
CUSTOS COLATERAIS DA VIOLÊNCIA NO BRASIL: RUMO A UM DIREITO MOLDADO PELA INSEGURANÇA? *
}

\author{
Diego Werneck Arguelhes e Mariana Pargendler
}

COLLATERAL COSTS OF VIOLENCE IN BRAZIL: HOW INSECURITY IS SHAPING THE DEVELOPMENT OF BRAZILIAN LAW

\section{RESUMO}

O PRESENTE ARTIGO IDENTIFICA E ANALISA O IMPACTO CRESCENTE NO DIREITO BRASILEIRO DAS CHAMADAS POLITICAS ADAPTATIVAS À INSEGURANC,A, ENTENDIDAS COMO MEDIDAS QUE TOMAM O ESTADO DE VIOLÊNCIA COMO UM DADO DA REALIDADE NACIONAL E ADAPTAM O REGIME JURÍDICO AO CENÁRIO DE INSEGURANÇA VIGENTE. DIFERENTEMENTE DAS TÍPICAS POLÍTICAS REPRESSIVAS À VIOLÊNCIA, QUE NÄO RARO FRAGILIZAM DIREITOS INDIVIDUAIS DE POTENCIAIS OFENSORES EM NOME DE UMA POLÍTICA GERAL DE SEGURANÇA PÚBLICA, AS POLÍTICAS ADAPTATIVAS À INSEGURANÇA EXPRESSAM UM FORTALECIMENTO DA PROTEÇÃO DOS DIREITOS INDIVIDUAIS DE POTENCIAIS VIITIMAS EM DETRIMENTO DE POLÍTICAS PÚBLICAS VOLTADAS À PROMOÇÃO DE OUTROS VALORES SOCIAIS RELEVANTES. DEMONSTRA-SE QUE AS POLÍTICAS ADAPTATIVAS TÊM GANHADO ESPAÇO NOS MAIS DIVERSOS RAMOS DO ORDENAMENTO JURÍDICO NACIONAL, INFLUENCIANDO ÁREAS APARENTEMENTE TÃO DÍSPARES E ESTRANHAS À PROBLEMÁTICA DA INSEGURANÇA COMO O DIREITO COMERCIAL, O DIREITO ADMINISTRATIVO E ATÉ MESMO AS REGRAS DE TRÂNSITO. DEFENDE-SE QUE, NÃO OBSTANTE A SUA ACEITAÇÃO E INFLUÊNCIA CRESCENTES, TAIS MEDIDAS NÃO PODEM SER ACEITAS DE FORMA ACRÍTICA. CONQUANTO AMPLIEM A EXTENSÃO DE DIREITOS INDIVIDUAIS, AS POLÍTICAS ADAPTATIVAS À INSEGURANÇA PODEM VIR A GERAR CUSTOS SIGNIFICATIVOS - E TALVEZ INJUSTIFICÁVEIS - POR MEIO DO ENFRAQUECIMENTO DE OUTRAS POLITICAS E VALORES PÚBLICOS RELEVANTES.

\section{PALAVRAS-CHAVE}

Políticas Públicas; Segurança Pública; Políticas adaptativas; Direitos fundamentais; TransparênCIA; ACCOUNTABILITY.

\begin{abstract}
THIS ARTICLE IDENTIFIES AND ANALYZES THE GROWING IMPACT THAT VIOLENCE AND LACK OF SECURITY HAVE HAD ON LEGAL INSTITUTIONS IN BRAZIL. IN PARTICULAR, WE EXAMINE THE EMERGENCE OF WHAT WE TERM ADAPTIVE POLICIES, FOR WHICH WE MEAN POLICIES THAT SEEK TO ADAPT AN EXISTING OR PROPOSED LEGAL REGIME TO A STATE OF VIOLENCE THAT IS TAKEN AS GIVEN. IN CONTRAST TO TRADITIONAL REPRESSIVE POLICIES, WHICH TYPICALLY WEAKEN INDIVIDUAL RIGHTS OF POTENTIAL AGGRESSORS TO PROMOTE GREATER PUBLIC SECURITY, ADAPTIVE POLICIES STRENGTHEN THE INDIVIDUAL RIGHTS OF POTENTIAL VICTIMS TO THE DETRIMENT OF OTHER PUBLIC POLICIES AND SOCIAL VALUES. WE ARGUE THAT ADAPTIVE POLICIES HAVE GAINED IMPORTANCE IN DIFFERENT AREAS OF BRAZILIAN LAW, RANGING FROM ADMINISTRATIVE LAW AND SECURITIES REGULATION TO TRAFFIC RULES. WE SUGGEST, HOWEVER, THAT ADAPTIVE POLICIES SHOULD NOT BE ADOPTED WITHOUT CAREFUL CONSIDERATION OF THEIR IMPLICATIONS IN TERMS OF EFFICIENCY AND DISTRIBUTION. EVEN THOUGH ADAPTIVE POLICIES EXPAND THE SCOPE OF INDIVIDUAL RIGHTS, THEY MAY DO SO TO THE DETRIMENT OF OTHER RELEVANT PUBLIC POLICIES AND VALUES.
\end{abstract}

\section{KEYWORDS}

PUBLIC POLICIES, SECURITY; AdAPTIVE POLICIES;

FundAMENTAL RIGHTS; TRANSPARENCY; ACCOUNTABILITY. 


\section{INTRODUÇÃO}

A América Latina apresenta altos índices de criminalidade, os quais, em muitos países da região, exibiram tendência de crescimento nas últimas décadas (TELLA; EDWARDS; SCHARGRODSKY, 2010, p. 2; CERQUEIRA ET AL., 2007). Segundo algumas estimativas, a ocorrência de homicídios na América Latina é mais do que duas vezes maior do que a média mundial (PRILLAMAN, 2003). Um ambiente de alta criminalidade traz, por sua vez, prejuízos econômicos e sociais significativos. ${ }^{1}$ Os custos diretos da violência englobam tanto os prejuízos resultantes da ação criminosa (perda de vidas, lesões corporais, danos morais e materiais e o consequente desincentivo a investimentos gerado pela percepção de insegurança) como também as despesas com medidas de combate à violência, tanto públicas (e.g., gastos com o aparato policial, judicial e penitenciário) como privadas (e.g., travas, cães de guarda, seguranças).

A magnitude dos prejuízos gerados pela violência na região é expressiva. Alguns economistas estimam que os custos da violência na América Latina em 1997 tenham alcançado cerca de 14\% de seu Produto Interno Bruto (PIB), enquanto outros defendem que a renda per capita na região seria até $25 \%$ maior caso o nível de criminalidade existente fosse semelhante ao de outros lugares do mundo (TELLA; EDWARDS; SCHARGRODSKY, 2010). Por exemplo, em 2001, as filiais brasileiras da General Motors gastavam quase três dólares em segurança para cada dólar despendido em sua matriz norte-americana na mesma área (REVISTA VEJA, 2001a). Os estudos existentes sobre o tema estimam que os custos da violência no Brasil oscilam entre 3\% e 10,5\% do PIB (KAHN, 1999).

Este trabalho não tratará dos custos diretos da violência (por exemplo, vidas humanas perdidas) ou dos custos de medidas práticas voltadas para o combate à violência ou à sua prevenção (por exemplo, grades em prédios), tal como tem feito a literatura especializada sobre o tema (KAHN, 1999; CERQUEIRA ET AL., 2007). Ao contrário, cuidaremos de uma consequência mais sutil e despercebida, mas não menos importante, da violência e da falta de segurança: o seu impacto sobre o desenvolvimento do Direito no Brasil. Os custos indiretos da violência via alteração da ordem jurídica - os quais chamaremos, por praticidade, de custos jurídicos da violência - podem tomar duas formas diversas e não excludentes, originando-se tanto (i) de políticas combativas, que atuam direta e primariamente sobre os atores vistos como causadores da ameaça, por meio da criação de desincentivos para potenciais agressões, quanto (ii) de políticas adaptativas, que realizam um ajuste na ordem jurídica com o objetivo de proteger potenciais vítimas em face de um cenário de insegurança que é tomado como um dado inevitável da realidade na qual o ordenamento jurídico opera.

Os custos de políticas combativas são bastante conhecidos. Para além dos custos diretos oriundos do aparato policial, judicial e penitenciário, há muito se discute o risco de que ações exageradas de repressão à violência urbana (ou, em outros contextos, 
ao terrorismo) possam conduzir ao enfraquecimento de instituições fundamentais ao Estado de Direito e à democracia. ${ }^{2}$ Um processo penal excessivamente rigoroso, por exemplo, pode vir a colocar em risco certas garantias individuais constitucionalmente protegidas, tais como a presunção de inocência, o devido processo legal, a vedação à tortura e a proibição de penas cruéis. Políticas combativas podem, portanto, levar ao comprometimento de certos direitos individuais fundamentais para alcançar um objetivo social ou coletivo de segurança pública.

Se os custos potenciais de políticas combativas são bastante conhecidos, o mesmo não ocorre com o que chamamos de políticas adaptativas, isto é, medidas que tomam o estado de violência como um dado da realidade e adaptam o regime jurídico a esse cenário de insegurança por meio de um aumento na proteção a potenciais vítimas de violência. Nesse sentido, o principal objetivo deste trabalho é identificar e analisar o surgimento e o impacto crescente das políticas adaptativas à insegurança no Brasil. Isto é, busca-se demonstrar a influência ou pressão que a insegurança - independentemente de qualquer política pública conscientemente articulada de repressão criminal - tem exercido sobre os mais diversos ramos do Direito brasileiro no sentido de promover a adaptação, e não o combate, à violência. Essa adaptação tipicamente ocorre por meio do fortalecimento dos direitos de potenciais vítimas, muitas vezes em detrimento de políticas públicas voltadas a outros valores sociais relevantes.

As políticas adaptativas no Brasil têm operado de forma descentralizada e vêm moldando áreas do ordenamento jurídico que pouco se relacionam com a esfera do direito penal, o ramo por excelência para a discussão e execução de políticas de caráter combativo. De fato, a falta de segurança pública no país tem sido utilizada, com diferentes graus de sucesso, para moldar o desenvolvimento de instituições jurídicas em áreas aparentemente tão díspares como o direito comercial, o direito administrativo e até mesmo as regras de trânsito. Somente no ano de 2009, argumentos baseados na percepção de insegurança foram empregados para mitigar e até mesmo evitar a imposição de normas jurídicas que exigem a divulgação da remuneração de executivos em companhias abertas, a publicação dos salários de servidores públicos e a publicidade dos gastos com o cartão corporativo do Presidente da República.

Curiosamente, em todos os itens do elenco acima - meramente exemplificativo, não exaustivo - os argumentos relativos à insegurança propunham soluções que isentariam certos indivíduos do cumprimento de deveres jurídicos existentes ${ }^{3}$ em prejuízo do grau de transparência do mercado e da sociedade como um todo. E a transparência é, notoriamente, ao mesmo tempo, um dos mecanismos fundamentais para o funcionamento do Estado Democrático de Direito e um dos principais pressupostos para a eficiência econômica. A publicidade de informações relevantes representa tanto um dos mais importantes princípios constitucionais norteadores da ação da Administração Pública ${ }^{4}$ como um dos fundamentos da regulação do mercado de capitais no Brasil e no mundo. ${ }^{5}$ 
Nos termos da famosa apologia de Louis Brandeis à transparência, "a luz do sol é o melhor dos desinfetantes; a luz elétrica é o mais eficiente policial” (1914, p. 92). No Brasil contemporâneo, porém, tem prevalecido no senso comum a ideia de que a segurança individual de potenciais vítimas requer escuridão e opacidade. A vítima que não pode ser vista ou identificada também não pode ser atacada, ainda que a mesma opacidade contribua para a perpetuação ou recrudescimento da criminalidade de forma geral. Em ainda outros casos - como a polêmica em torno da obrigatoriedade da parada em semáforos no período noturno -, o direito individual à segurança opõe-se não somente a políticas públicas que promovam a transparência, mas até mesmo a políticas públicas que tenham como objetivo principal salvar vidas.

Esses exemplos ilustram a forma peculiar pela qual a insegurança tem modulado o desenvolvimento do Direito no Brasil. A tabela a seguir (Tabela 1) esquematiza e combina as distinções entre os custos diretos e indiretos da violência, de um lado, e entre a adaptação e o combate à violência, de outro:

\section{TABEla 1. Custos INDIRETOS E CUSTOS INDIRETOS (VIA ORDEM JURÍDICA) DA VIOLÊNCIA}

\begin{tabular}{|c|c|c|}
\hline & CUSTOS DA VIOLÊNCIA & $\begin{array}{l}\text { CUSTOS DE MEDIDAS } \\
\text { PREVENTIVAS E REPRESSIVAS }\end{array}$ \\
\hline DIRETOS OU FÁTICOS & $\begin{array}{l}\text { MORTES; DANOS CORPORAIS; DANOS À } \\
\text { PROPRIEDADE; DANOS PSICOLÓGICOS; } \\
\text { DESINCENTIVO A INVESTIMENTOS ETC. }\end{array}$ & $\begin{array}{l}\text { GASTOS COM OS SISTEMAS JUDICIAL, } \\
\text { POLICIAL E PENITENCIÁRIO ETC. }\end{array}$ \\
\hline \multirow[t]{3}{*}{ INDIRETOS OU JURÍDICOS } & “POLÍTICAS ADAPTATIVAS” & “POLÍTICAS COMBATIVAS” \\
\hline & $\begin{array}{l}\text { FORTALECIMENTO DE DIREITOS INDIVIDUAIS } \\
\text { DE SEGURANCCA POR PARTE DE POTENCIAIS } \\
\text { VÍTIMAS EM DETRIMENTO DE POLÍTICAS } \\
\text { PÚBLICAS DE EFEITOS COLETIVOS. }\end{array}$ & $\begin{array}{l}\text { PROMOÇÃO DE POLÍTICAS DE } \\
\text { SEGURANÇA PÚBLICA EM DETRIMENTO } \\
\text { DE DIREITOS INDIVIDUAIS DE SUSPEITOS } \\
\text { E ACUSADOS CRIMINAIS. }\end{array}$ \\
\hline & $\begin{array}{l}\text { EXEMPLOS: MENOR TRANSPARÊNCIA } \\
\text { QUANTO AOS SALÁRIOS DE EXECUTIVOS } \\
\text { DE COMPANHIAS ABERTAS E FUNCIONÁRIOS } \\
\text { PÚBLICOS; DISTORÇÕES EM REGRAS }\end{array}$ & $\begin{array}{l}\text { EXEMPLOS: FRAGILIZAÇÃO DO DIREITO } \\
\text { À AMPLA DEFESA, DA PRESUNÇÃO DE } \\
\text { INOCÊNCIA, DA VEDAÇÃO À TORTURA, } \\
\text { DA PROIBIC̦ÃO A PENAS CRUÉIS ETC. }\end{array}$ \\
\hline
\end{tabular}

Como veremos na segunda parte deste trabalho, todos os exemplos elencados apontam para situações em que a percepção de excessiva violência ou insegurança no país pode conduzir as instituições jurídicas a tomarem uma forma diferente daquela que seria provavelmente ideal em um ambiente de menor violência. No entanto, busca-se problematizar a conclusão de que tais adaptações seriam necessariamente second-best (ou segundas melhores alternativas), para usar o jargão de teoria econômica. ${ }^{6}$ Pretende-se 
sugerir que as políticas adaptativas à violência podem trazer consigo custos jurídicos significativos - e talvez injustificáveis - por meio do enfraquecimento de outras políticas públicas relevantes. Sob uma perspectiva dinâmica, portanto, tais políticas adaptativas podem vir a retardar o desenvolvimento do país e a consequente superação das próprias causas econômicas e sociais da violência. ${ }^{7}$

A análise da relação entre a insegurança e a evolução da ordem jurídica será abordada da seguinte forma: a segunda parte descreverá casos que ilustram o uso de argumentos de insegurança para influenciar o conteúdo e a aplicação de regras nos mais diversos ramos do Direito. A terceira parte trará uma breve digressão sobre o debate concernente à relação entre Direito e insegurança, buscando-se mostrar como o foco da literatura existente em políticas combativas não se revela adequado para compreender a estrutura e as possíveis implicações das políticas adaptativas descritas na segunda parte. Na quarta e última parte, serão exploradas algumas possíveis implicações normativas dos custos jurídicos da violência anteriormente descritos.

\section{i Argumentos de insegurança no Direito brasileiro}

\section{I INSEGURANÇA E MERCADO DE CAPITAIS}

Nas últimas décadas, formou-se um crescente consenso econômico no sentido de que a existência de mercado de capitais robusto opera como causa, e não somente como consequência, do desenvolvimento econômico de um país (exemplificativamente nesse sentido, KING; LEVINE, 1993). Como decorrência de importantes inovações institucionais promovidas pela Bolsa de Valores de São Paulo e de uma conjuntura macroeconômica favorável na última década, o mercado de capitais brasileiro escapou do estado de quase aniquilação em que se encontrava ao final dos anos 1990 para se transformar em um dos mais ativos mercados de ações no mundo, o qual tem servido de modelo para outros países em desenvolvimento. Nos últimos anos, a confiança gerada pelo mercado brasileiro pode ser atribuída não somente a inovações institucionais iniciadas por via contratual como também ao crescente ativismo da Comissão de Valores Mobiliários (CVM) quanto à proteção dos direitos dos acionistas minoritários (GILSON; HANSMANN; PAR GENDLER, 2011).

A partir de 2009, a CVM buscou suprir uma das mais significativas deficiências do Direito brasileiro com relação aos padrões internacionais de regulação do mercado de capitais. Dentre as inovações previstas para uma nova instrução normativa sobre os deveres de informar das companhias abertas no Brasil, destacou-se a exigência de divulgação de informações específicas relativas aos salários pagos aos principais executivos de companhias abertas. Essa proposta gerou, desde a fase de audiência publica relativa à nova regulamentação, intensa reação negativa por parte das companhias e executivos afetados. 
O principal argumento utilizado pelos opositores da reforma foi, talvez surpreendentemente, o elevado nível de violência no Brasil. Como bem capturado pela cobertura da mídia,

curiosamente no Brasil esse tema [divulgação dos salários de executivos] tem sido visto menos pelo lado da gestão corporativa e mais pelo ângulo, digamos, policial. Há quem acredite, por exemplo, que a divulgação desses dados pode comprometer a segurança dos executivos, já que eles se tornariam alvo potencial de ações criminosas, como sequestros (CASTANHEIRA, 2009).

Embora a divulgação dos salários dos principais executivos de uma companhia aberta represente prática já consagrada em outros países com mercado de capitais desenvolvido (e familiar na história do $\mathrm{Brasil}^{8}$ ), os opositores da reforma fundaram-se justamente nas características peculiares da realidade brasileira quanto à falta de segurança pública para esquivar-se do novo mandamento. A Associação Brasileira de Companhias Abertas (ABRASCA) manifestou-se no sentido de que "[m]esmo que esses dados [relativos à remuneração individualizada dos executivos] tenham utilidade aos investidores, não é aconselhável que as empresas os divulguem dada a nossa realidade, de grandes problemas de segurança” (VALOR ECONÔMICO, 2009).

A preocupação inicial da CVM com o fator segurança, ${ }^{9}$ aliada à veemente oposição das companhias abertas durante a fase de audiência pública, levou a Comissão a abandonar a sua proposta original, a qual previa a exigência de divulgação individualizada dos vencimentos de cada executivo (MEDEIROS, 2009). A posição conciliatória refletida na regulamentação posteriormente promulgada com a Instrução n. 480/2010 previu, no que tange ao detalhamento do quantum remuneratório, tão somente a divulgação da maior, menor e média remuneração pagas aos membros do Conselho de Administração, da Diretoria e do Conselho Fiscal. ${ }^{10}$ Tal norma, ainda assim, representou importante avanço quanto ao regime anterior, o qual somente exigia a divulgação dos gastos globais com folha salarial de executivos, sem qualquer detalhamento quanto a cargos e salários. ${ }^{11}$

Até mesmo essa solução intermediária, que fica aquém da legislação de outros países, foi severamente criticada no contexto brasileiro. O Senador Francisco Dornelles (PP-RJ) manifestou-se publicamente no sentido de que "a maior transparência objetivada pela norma pode acarretar perigos à segurança pessoal desses administradores e suas famílias" e poderá ser "de grande utilidade a criminosos na seleção de suas vítimas” (AGÊNCIA SENADO, 2010). O tema foi, inclusive, objeto de contestação judicial.

Em ação proposta pelo Instituto Brasileiro de Executivos de Finanças, a Justiça Federal suspendeu liminarmente a aplicação dos dispositivos relativos à remuneração 
de executivos previstos pela Instrução n. 480/2010. Nesse processo, o autor listou como principais argumentos a ilegalidade da ação da CVM por exceder o seu poder regulamentar, a inconstitucionalidade das novas exigências por ofensa ao direito constitucional à privacidade e o risco criado por tais regras à própria segurança pessoal do executivo e de sua família. A decisão liminar suspendendo a eficácia do dever de divulgação fundamentou-se, entre outras razões, no argumento relativo à insegurança. Segundo o juiz do caso,

[e]m um país com imensas desigualdades sociais e com um alto índice de violência, com a sofisticação dos agentes criminosos, dados financeiros, revelados pela internet, constituem meios de informação que põem em risco não somente os executivos, mas também os seus familiares. O argumento possível de que isso ocorre em outras plagas não é de molde a importar, automaticamente, normas sem a necessária adequação [...]. ${ }^{12}$

O mesmo argumento foi repetido pelo juiz na sentença que ratificou a liminar concedida:

Analisando-se a presente demanda por outro viés, é forçoso reconhecer que a divulgação da remuneração dos executivos pela rede mundial de computadores teria o condão de comprometer a segurança tanto dos referidos profissionais quanto a de suas famílias, haja vista a atuação cada vez mais especializada e violenta dos criminosos. ${ }^{13}$

Os efeitos colaterais e inusitados da violência no desenho regulatório do mercado de capitais no Brasil - reconhecidamente importante para o seu desenvolvimento econômico - produzem interessantes questões de ordem teórica e prática. De um lado, a divulgação de informações relevantes ocupa um papel fulcral para a eficiência do mercado de capitais e para a proteção dos investidores e, por isso mesmo, constitui o princípio norteador da ação regulatória sobre o mercado de capitais nos mais diversos ordenamentos jurídicos. A ausência de individuação dos salários pagos aos executivos seria potencialmente ainda mais prejudicial no contexto brasileiro, no qual grande parte das empresas listadas apresenta controle familiar concentrado; não é de surpreender, pois, que o investidor tenha interesse em saber se certa quantia foi paga a um administrador profissional ou a um membro da família controladora. De outro lado, o risco à integridade física de seus dirigentes afeta a gestão da companhia e, em última análise, os interesses dos acionistas minoritários. É plausível que os acionistas de companhias abertas venham a internalizar - por meio de maiores salários ou de dispendiosas medidas de proteção - os custos causados aos executivos pela nova legislação, por meio de menores retornos aos seus investimentos. Por fim, 
cumpre ressaltar que o crescente abismo entre os salários de executivos de grandes empresas e aqueles pagos ao trabalhador médio tem se tornado o ponto focal do debate sobre o aprofundamento da desigualdade social ao redor do mundo nas últimas décadas. ${ }^{14}$ Dessa forma, a violência no Brasil poderia ter o efeito colateral de silenciar um dos meios para o debate de tema tão relevante ao desenvolvimento nacional.

\section{I.2 Insegurança e Administração Pública}

\section{i.2. i Publicidade de salários de Servidores públicos}

No dia 16 de junho de 2009, a Prefeitura do Município de São Paulo anunciou a consolidação e a disponibilização, no sítio eletrônico "De Olho nas Contas", 15 de informações individualizadas relativas à remuneração bruta recebida por quase todos os 162 mil funcionários do Município, à exceção da Guarda Civil Metropolitana (GCM). ${ }^{16}$ Segundo nota oficial da Prefeitura, a inclusão dessas informações no recém-lançado "Portal da Transparência" seria "uma ferramenta que permite ao cidadão paulistano ter acesso a uma série de informações sobre a vida financeira da Prefeitura”, possibilitando, assim, uma maior fiscalização sobre o uso dos recursos públicos. ${ }^{17} \mathrm{~A}$ maior parte dessas informações já estava formalmente disponível ao público, mas dispersa em locais e formatos pouco acessíveis no âmbito da burocracia municipal. Nesse sentido, a grande inovação do "De Olho nas Contas" e do "Portal da Transparência” estaria na tentativa de:

[...] reunir, em um só local do Portal da Cidade de São Paulo, todos os dados já disponíveis e outros necessários relacionados a tais gastos [públicos], para que cada um dos munícipes possa fiscalizar diretamente as contas públicas, ao acessar as listagens dos contratos públicos, com respectivos pagamentos, bem como aquelas que contêm o nome, a lotação, o cargo e vencimentos brutos de cada um dos servidores da Prefeitura. ${ }^{18}$

As reações à medida foram imediatas. O "Portal da Transparência" registrou mais de 70 mil acessos em seu primeiro dia no ar. ${ }^{19}$ A remuneração bruta originalmente apresentada no site não discriminava entre salário e outras indenizações (resultantes, por exemplo, de vitórias judiciais do funcionário contra a Prefeitura e incluídas diretamente na folha de pagamento), mas esse tipo de nuance não impediu o surgimento de um pequeno escândalo na imprensa. Nesse primeiro momento, houve destaque especial para o fato de 1.600 a 2.400 funcionários do município, dependendo de qual veículo de comunicação fizesse a estimativa, estarem aparentemente recebendo remuneração acima do teto municipal de R \$ 12,3 mil. ${ }^{20}$

De um lado, organizações da sociedade civil saudaram a medida como uma forma eficaz de promover a transparência na Administração Pública. ${ }^{21}$ De outro, sindicatos 
de diversas categorias de funcionários públicos da Cidade de São Paulo questionaram imediatamente a medida na imprensa. Embora diversos argumentos tenham sido apresentados por esses atores, a mídia conferiu maior destaque à consideração de que o novo veículo para a divulgação de informações poderia vir a colocar em risco a segurança pessoal dos servidores. Por exemplo, Cláudio Fonseca, Presidente do Sindicato dos Profissionais em Educação no Ensino Municipal de São Paulo (SINPEEM), fez as seguintes declarações em diversos veículos de comunicação nos dias subsequentes à entrada do Portal da Transparência no ar:

É uma imprudência do governo. Vivemos numa era de insegurança total. Não acho que isso contribui em nada e ainda expõe o servidor público à insegurança, a golpes eletrônicos, tudo isso. ${ }^{22}$

Eles [os funcionários da Prefeitura de São Paulo] podem virar isca de ladrão. ${ }^{23}$

A Prefeitura expôs desnecessariamente os servidores, já que muitos dos valores divulgados vêm de disputas judiciais travadas há anos. A medida coloca ainda os funcionários sob ameaças de roubo e sequestro. ${ }^{24}$

Quadrilhas acompanham todos os atos legais [da Prefeitura] e sabem o dia em que os servidores recebem seus vencimentos [...] [A divulgação] acaba com o sigilo fiscal e torna-nos reféns de eventuais golpes eletrônicos ou mesmo vítimas de assaltos. 25

Paralelamente às críticas ao Portal na imprensa, os sindicatos começaram a questionar judicialmente a divulgação dos dados pela Prefeitura. Essas organizações conseguiram, no âmbito do Tribunal de Justiça do Estado de São Paulo, a suspensão da divulgação, em caráter liminar, por meio do Mandado de Segurança n. 180.176-0/7-00. Derrotada em $1^{\mathrm{a}}$ e em $2^{\mathrm{a}}$ instância na Justiça Estadual, a Prefeitura de São Paulo ajuizou um pedido de Suspensão de Segurança (SS) junto ao Supremo Tribunal Federal.

Em todos esses debates judiciais, da $8^{\text {a }}$ Vara de Fazenda Pública da Comarca da Capital ao STF, as duas entidades mencionadas apresentaram uma série de argumentos, formais e substanciais, para justificar a necessidade de se declarar a inconstitucionalidade da divulgação de seus salários. Para os nossos fins, interessam os argumentos de direitos fundamentais empregados: o ato do Prefeito violaria os direitos dos servidores à intimidade e à segurança, ambos previstos no artigo $5^{\circ}$ da Constituição. Esses argumentos foram adotados pelo próprio Desembargador do TJSP na decisão liminar cuja suspensão era discutida no STF: a divulgação no sítio eletrônico não seria admissível porque colocaria em risco "a segurança pessoal e patrimonial dos servidores”. 26

Por sua vez, a Prefeitura de São Paulo alegava junto ao Ministro Gilmar Mendes, relator da Suspensão de Segurança n. 3.902, que as liminares concedidas pelo TJSP 
causariam graves lesões à ordem pública por violarem o princípio constitucional da publicidade (art. 37, caput, e incisos XIV e XXXIII do artigo $5^{\circ}$ da Constituição Federal) - uma exigência constitucional de transparência na Administração Pública que o "Portal da Transparência" buscava concretizar. Argumentavam, ainda, que há regras constitucionais especificamente aplicáveis à publicidade dos salários dos servidores públicos, que refletem uma opção prévia do constituinte de fazer prevalecer a transparência na divulgação desses valores. ${ }^{27}$

Embora o instrumento processual da Suspensão de Segurança sirva apenas para se suspender a concessão de liminares de modo a "evitar grave lesão à ordem, à saúde, à segurança e à economia públicas”, o Ministro Gilmar Mendes não se limitou a fazer um juízo sobre as possíveis consequências desastrosas dessas decisões liminares atacadas pela Prefeitura de São Paulo. Ao realizar uma análise preliminar quanto ao mérito das ações em curso, o Ministro Mendes levou a sério os argumentos de direitos fundamentais e princípios constitucionais apresentados por ambas as partes, afirmando que, em última instância, o problema de constitucionalidade a ser resolvido no caso:

está em saber se a divulgação da remuneração bruta mensal vinculada ao nome de cada servidor municipal, em sítio eletrônico na Internet denominado "De Olho nas Contas", de domínio da municipalidade, significa: (1) a concretização do princípio da publicidade (art. 37, CF/88) e o dever de transparência com os gastos públicos; ou (2) a exposição indevida de um aspecto da vida do servidor público - dado pessoal, protegido pela inviolabilidade da intimidade, da vida privada, da honra e da imagem dos servidores; ou (3) a violação da garantia da segurança da própria sociedade e do Estado - art. $5^{\circ}$, XXXIIII, CF/88 (sociedade, no caso, constituída pelos servidores públicos municipais e por aqueles que dele dependem). ${ }^{28}$

A formulação do Ministro Mendes implicitamente reconstrói o problema como uma aplicação do exame de proporcionalidade. As três etapas que tipicamente compõem esse teste (adequação, necessidade e proporcionalidade em sentido estrito) ${ }^{29}$ não estão explícitas na decisão monocrática do Ministro Mendes. Ainda assim, é possível identificar na questão (1) supramencionada na decisão um anúncio de um futuro exame de adequação, que deverá responder à seguinte pergunta: a divulgação dos nomes e salários dos servidores públicos contribui para a promoção do objetivo de transparência, previsto no artigo 37 da Constituição, dentre outros dispositivos? Além disso, a resposta afirmativa a esse exame de adequação não põe fim ao juízo de constitucionalidade; o Ministro Mendes deixou claro que mesmo uma medida que promova o fim constitucional legítimo de maior publicidade e transparência administrativas 
pode não ser constitucional. A questão, portanto, é saber o quanto de interferência na privacidade (2) e na segurança pessoal (3) dos servidores é constitucionalmente justificada no caso da medida adotada em São Paulo.

Essas questões não foram deixadas completamente em aberto na decisão. De fato, embora tenha julgado procedente o pedido da Prefeitura de São Paulo na SS n. 3.902 e suspendido as liminares que impediam a permanência do Portal da Transparência no ar, a decisão do Ministro Gilmar Mendes mostrou-se receptiva aos argumentos constitucionais de ambas as partes. De um lado, reconheceu que a planilha de dados contida no site:

em princípio permitiu constatar a existência de diversas remunerações mensais e remunerações totais brutas que excedem, aparentemente, não só o teto remuneratório municipal, mas, em alguns casos, até mesmo o teto remuneratório federal, com valores que quase alcançam $\mathrm{R} \$ 50.000,00$.

De outro lado, porém, o Ministro acenou para as questões de segurança pessoal levantadas pelos servidores, reconhecendo as falhas no Portal da Transparência já levantadas pela mídia e observando o seguinte:

a Administração poderá sempre buscar soluções alternativas ou intermediárias. No caso em questão, uma solução hipoteticamente viável para a finalidade almejada seria a substituição do nome do servidor por sua matrícula funcional. ${ }^{30}$

Em síntese, portanto, a decisão monocrática do Ministro do STF expressa o entendimento de que (a) a policy da Prefeitura é razoavelmente adequada para atingir o fim constitucional pretendido, mas que (b) devem ser considerados meios alternativos que possam, simultaneamente, promover o objetivo de publicidade e impor menores restrições à privacidade e à segurança pessoal dos servidores. Essa tensão tem uma forma familiar: a de um conflito entre princípios constitucionais que pode ser resolvido por meio de um exame de proporcionalidade.

Ao apreciar a questão em Agravo Regimental, em junho de 2011, o Plenário do Supremo Tribunal Federal seguiu o mesmo caminho da decisão monocrática do Ministro Gilmar Mendes. Por unanimidade, todos os Ministros decidiram pela prevalência da publicidade administrativa neste caso. Mais uma vez, porém, não se rejeitou o argumento de segurança empregado para contestar o "De Olho nas Contas", como pode ser observado no voto do Relator da decisão, Min. Carlos Ayres Britto:

[Q]uanto à segurança física ou corporal dos servidores, seja pessoal, seja familiarmente, claro que ela resultará um tanto quanto fragilizada com a 
divulgação nominalizada dos dados em debate, mas é um tipo de risco pessoal e familiar que se atenua com a proibição de revelar o endereço residencial [e] o CPF [...] de cada servidor. No mais, é o preço que se paga pela opção por uma carreira pública no seio de um Estado republicano. ${ }^{31}$

Assim, reconhece-se que o site "De Olho nas Contas" poderia, de fato, "fragilizar" a segurança pessoal dos servidores - e que isso é uma restrição a um direito fundamental que só pode ser considerada constitucional mediante justificação especial. O argumento de segurança foi, portanto, tratado como um argumento de direitos fundamentais válido. Apenas se entendeu que esse princípio constitucional deveria ceder ao da publicidade administrativa neste caso específico. Retornaremos a este problema de proporcionalidade e às suas implicações no item 3, infra. Por ora, cumpre destacar que uma medida da Prefeitura de São Paulo voltada para a promoção de maior publicidade, transparência e accountability da administração municipal foi contestada política e judicialmente com base no que definimos neste artigo como um argumento de segurança. Os representantes dos servidores públicos defenderam que, dada a situação de insegurança vigente na cidade de São Paulo, a divulgação online de seus nomes e salários é inconstitucional na medida em que criará um estado de coisas em que o seu direito individual à segurança será ainda mais erodido. Embora a questão ainda não tenha sido decidida em definitivo pelo Supremo Tribunal Federal, é importante notar que o argumento de segurança utilizado para contestar a política pública de transparência foi levado a sério pelo tribunal. ${ }^{32}$

\section{2.2 CARTÕes COR PORATIVOS E Gastos PRESidenciais}

Ainda no âmbito da Administração Pública, a segurança tem aparecido como o principal argumento para evitar a divulgação dos gastos crescentes da Presidência da República com os chamados “cartões corporativos”. Os cartões corporativos para uso do Governo Federal, instituídos em 2001, ainda na Administração de Fernando Henrique Cardoso, começaram a ser utilizados no primeiro ano do Governo Lula. Tais cartões - destinados a despesas "esporádicas e emergenciais" - foram criados com o objetivo de substituir o sistema anterior no qual o servidor recebia reembolso mediante a comprovação de pagamento de despesas elegíveis. Todavia, observou-se nos últimos anos um crescimento exponencial dos gastos efetuados por meio de cartões corporativos do Governo Federal. Revelados pela mídia, gastos injustificados em restaurantes e free shops, totalizando $\mathrm{R} \$ 171 \mathrm{mil}$ em apenas um ano, levaram a Ministra da Igualdade Racial a perder o seu cargo. Os gastos da Presidência da República com cartões corporativos, entretanto, continuaram em tendência crescente em 2009, atingindo R \$ 5,3 milhões no período de janeiro a dezembro (LUIZ; TORRES, 2009).

No âmbito da Presidência da República, porém, a alocação de grande parte dessa quantia - despendida sem necessidade de processo de licitação, a forma usual de 
contratação por parte do Poder Público no Brasil - permanece secreta. O argumento defendido contra um regime de maior transparência é, novamente, a segurança seja “a segurança de Lula, José Alencar e de seus familiares, tanto em Brasília quanto nos locais onde eles residem ou estejam em deslocamentos" ou a própria "segurança nacional”. ${ }^{33}$ Os governantes, portanto, também têm recorrido ao poder argumentativo da segurança contra a transparência - um artifício que, até o momento, não parece ter sido suficientemente contestado pela sociedade.

\section{I.3 INSEGURANÇA E REGRAS DE TRÂNSITO}

\section{I . 3. I INSUlfilm **}

As controvérsias anteriormente descritas não são os únicos exemplos de utilização da violência como argumento para justificar a opacidade. Outra situação em que a violência conduziu a uma redução da transparência - aqui em um sentido menos metafórico e mais literal - é a crescente utilização de insulfilm em veículos automotores. O chamado insulfilm é a película, cada vez mais utilizada por motoristas no Brasil, que escurece os vidros dos automóveis, diminuindo a sua transparência e visibilidade interior.

O marketing do insulfilm baseia-se, em grande parte, em apelos à segurança do motorista (FOLHA DE S. PAULO, 2003). Em edição especializada sobre a violência, a Revista VEJA recomendou aos seus leitores o uso da película escurecedora, a qual "inibe os assaltos porque, com dificuldade de ver o interior do carro, o bandido não se sente seguro para agir” (2001b). A lógica antibrandeisiana da opacidade funda-se na percepção de que a falta de visibilidade interior desencorajaria ataques por parte de criminosos, os quais não teriam como determinar o porte do motorista ou a possibilidade de que este esteja armado. O insulfilm tem sido adotado de forma crescente por mulheres, vítimas mais visadas da violência urbana e que se sentem, portanto, mais protegidas por essa "invisibilidade".

A conexão insulfilm-segurança contribuiu para a rápida difusão do uso da película e para mudanças na regulação que inicialmente restringia o seu uso. A utilização de insulfilm era ilegal no Brasil até 1998, pois se entendia que a película dificultava a fiscalização de infrações por parte de policiais e guardas de trânsito. Os níveis de escurecimento permitidos em 1998 foram novamente ampliados em 2007, após um processo de deliberação no qual preponderaram os pedidos de motoristas que se sentiam protegidos pela película sobre as reclamações da polícia no sentido de que a falta de visibilidade no interior dos veículos dificultava a sua fiscalização. Segundo a descrição da controvérsia pela mídia brasileira, "[p]ara alguns motoristas, o escurecimento ajuda na proteção contra assaltos, principalmente em casos de crianças transportadas nos bancos de trás. Para as polícias, o escurecimento excessivo dificulta a identificação e prisão de criminosos" (CARVALHO; WEBER, 2007). A polêmica 
em torno do insulfilm, aparentemente singela, ilustra de forma eficaz como as políticas adaptativas à violência no Brasil podem produzir até mesmo um conflito entre políticas gerais de segurança pública, de um lado, e a afirmação de direitos individuais à segurança, de outro.

\section{I $\cdot 3 \cdot 2$ Sinal Vermelho}

A par do insulfilm, a violência também tem moldado o conteúdo de normas de trânsito ainda mais triviais, como a obrigatoriedade de os automóveis pararem diante de um sinal vermelho à noite. A utilidade prática de semáforos trifásicos para a coordenação do tráfego e a prevenção de acidentes dispensa maiores elaborações. $\mathrm{O}$ que cumpre destacar, aqui, é um lugar-comum que soa familiar para qualquer habitante de grande cidade no Brasil: a exigência legal de parar em semáforo coloca em risco a segurança do motorista em certos períodos do dia e em certas áreas da cidade. ${ }^{34}$ Em estudo publicado em 2007, por exemplo, um representante da Empresa de Transportes e Trânsito de Belo Horizonte (BHTRANS) observou o seguinte:

Diariamente, a empresa [BHTRANS] recebe uma série de solicitações [...] em relação ao funcionamento dos semáforos no período noturno. Nesses registros, os usuários solicitam a adoção de semáforos em amarelo piscante, apagados ou que se reduza o tempo de espera nos horários noturnos. Com aumento da sensação de insegurança nas interseções semaforizadas, principalmente no período noturno, o número de solicitações vem se tornando cada vez mais frequente (PINTO JUNIOR, 2007).

As adaptações do Direito a este problema têm tomado as mais diversas formas. Alguns municípios optaram por abandonar a tradicional forma trimodal de sinalização no período noturno, adotando, em seu lugar, o sinal amarelo intermitente, que sugere aos motoristas atenção nos cruzamentos sem, contudo, estabelecer uma clara ordem de prioridade. ${ }^{35}$ Em outras localidades, a sinalização tradicional foi mantida, mas a fiscalização e a punição por desrespeito à sinalização ou por excesso de velocidade ocorridas à noite foram reduzidas ou até eliminadas. Na cidade do Rio de Janeiro, por exemplo, a Lei n. 4.892/2008, ainda em vigor, dispõe que "o Poder Executivo Municipal não poderá utilizar sistemas eletrônicos de aferição de velocidade, que estejam instalados em áreas de risco para segurança dos motoristas, após as $22 \mathrm{~h} 00 \mathrm{~min} " 36$

Nos casos em que as autoridades executivas e legislativas não reagiram ao problema com uma política estruturada, a adaptação veio de forma descentralizada, pela via judicial. O número de multas por desrespeito ao sinal vermelho à noite cresceu exponencialmente nos últimos anos, e o Judiciário, por sua vez, tem anulado multas por considerá-las desproporcionais em face do risco de violência (ALVES, 2009). De 
fato, este é um dos mais paradigmáticos exemplos da receptividade do Judiciário brasileiro a argumentos de segurança em prol de políticas adaptativas. Em amplamente divulgado acórdão, ${ }^{37}$ a $17^{\text {a }}$ Câmara Cível do TJRJ decidiu da seguinte forma:

A situação de perigo e de grave risco à vida decorrente da descontrolada violência urbana endêmica da cidade do Rio de Janeiro constitui fato público e notório, assumindo dimensões tais só comparáveis, em números de mortes e mutilados, a territórios flagelados pela guerra. A situação é mais grave especialmente à noite quando a cidade se torna praticamente despoliciada e o cidadão fica entregue à própria sorte, sendo obrigado a adotar táticas de sobrevivência, como o avanço cauteloso de sinais luminosos e a não observância de limites muito reduzidos de velocidade em áreas reconhecidamente de risco. Ao assim proceder, o motorista busca evitar a ação de delinquentes que, não raro drogados e quase sempre em quadrilha fortemente armada, atacam a pé, de motocicleta ou de carro e estão dispostos a praticar atos extremos de violência, alvejando para matar até mesmo quando não há reação da vítima. Em casos tais e diante das circunstâncias especialíssimas e de exceção da atualidade, impõe-se uma inversão da presunção de legitimidade do ato administrativo, competindo ao Poder Público demonstrar que no local e horário da infração de trânsito proporcionava ao cidadão infrator meios razoáveis de segurança, podendo dele exigir conduta diversa. ${ }^{38}$ (grifamos)

Após essas quase literárias e extremamente gráficas considerações sobre o estado de violência no Rio de Janeiro, o Relator Desembargador do acórdão cita ainda a já mencionada Lei n. 4.892/2008, a qual, apesar de não aplicável a sinais de trânsito, e "embora posterior ao fato objeto da lide, reforça a idéia de que o Poder Público que não cumpre sua obrigação de zelar pela segurança do cidadão não pode dele exigir, em situação de risco, a observância de regras que potencializam tal risco". ${ }^{39} \mathrm{Ou}$ seja, mesmo na ausência de lei específica aplicável, entendeu-se que, diante da situação de insegurança, não seria razoável punir o cidadão por violação ao sinal vermelho no período noturno.

É certo, porém, que essas políticas adaptativas à violência pelo abandono das regras tradicionais de trânsito não são isentas de custos. A incerteza e a falta de coordenação introduzidas mesmo por medidas moderadas como a adoção de sinais intermitentes podem vir a contribuir para um aumento do número de acidentes. ${ }^{40}$ Em alguns municípios, houve, inclusive, um retorno à sinalização convencional em virtude de drástico crescimento na quantidade de acidentes causados após a implementação de medidas adaptativas. ${ }^{41}$ Em muitos outros, porém, a perspectiva do direito individual do motorista à segurança tem prevalecido sobre as políticas de segurança no trânsito, como no 
caso do Rio de Janeiro. Esta situação é particularmente interessante em função de importar a ponderação de medidas que visam promover valores idênticos, isto é, a proteção à vida e à integridade física.

Vale insistir que, nesta seção, não se pretendeu oferecer uma lista exaustiva dos argumentos de segurança e políticas adaptativas existente no Direito brasileiro. Existem vários outros exemplos de adaptações do ordenamento jurídico a situações de violência que não foram aqui mencionados. ${ }^{42}$

\section{INSEGURANÇA E TRANSFORMAÇÕES DO DIREITO: A NARRATIVA TÍPICA}

Nesta seção, busca-se reconstruir brevemente alguns dos principais debates existentes sobre o impacto da insegurança sobre a ordem jurídica - debates que, de um modo geral, concentram-se quase exclusivamente sobre as chamadas políticas combativas à insegurança. A pretensão não é exaurir o tema, nem arbitrar de forma definitiva as diversas questões em aberto nessa literatura, mas sim analisar em que medida o aparato conceitual utilizado no debate sobre políticas repressivas é pertinente para se discutir as implicações de políticas adaptativas como as descritas na seção anterior.

Há numerosos estudos de casos históricos, jurídicos e políticos que discutem as relações entre situações percebidas como emergências nacionais - guerras externas ou internas, desastres naturais, crises econômicas ou qualquer situação em que a comunidade se perceba ameaçada de forma grave - e as respostas a esses eventos no campo do Direito. ${ }^{43}$ Os exemplos de transformação nos arranjos jurídicos existentes nesses contextos são muitos - e familiares. ${ }^{44}$ Em alguns casos de insegurança e emergências extremas, chega-se a discutir se e em que condições a legalidade pode ser suspensa, possibilitando a adoção, pelo Estado, de medidas inaceitáveis em situações normais (BARAK, 2003; BRANDON, 2005). Evidentemente, se tais ações já seriam controvertidas em cenários extremos (como no caso de guerra externa e declarada), sua plausibilidade se reduz quase a zero em um cenário de insegurança mais difusa e, a princípio, permanente (TUSHNET, 2005, p. 45).

No entanto, o emprego de argumentos de segurança nacional para justificar rupturas parciais ou simples transformações na legalidade existente, no sentido de aumentar o poder repressivo do Estado, são fenômenos infelizmente familiares na história da América Latina. No caso do Brasil, a experiência mais clara nesse sentido possivelmente ocorreu durante o Estado Novo de Getúlio Vargas. Embora na prática muitos dos dispositivos da Constituição brasileira de 1937 não tenham tido efetividade alguma, ${ }^{45}$ o seu texto reflete um compromisso básico de transformar o caráter do Direito vigente para fazer frente a uma situação considerada emergencial. ${ }^{46}$ As restrições a direitos fundamentais e a estruturas democráticas foram explicitadas e justificadas no preâmbulo da Constituição como necessárias para assegurar o desejo - supostamente 
manifestado pela sociedade e atendido por Vargas - de manter a "paz social" no país. ${ }^{47}$ Mais ainda, Vargas foi responsável por introduzir a primeira legislação sistemática e específica sobre crimes contra a segurança nacional da história brasileira. ${ }^{48}$

O regime militar brasileiro de 1964-1985 também procurou converter em direito positivo - e de forma ainda mais acentuada do que na Era Vargas - a demanda por mais poder repressivo para fazer frente a uma suposta situação de insegurança. Embora tenha havido uma série de claras rupturas constitucionais sob a forma de atos institucionais, o regime não suspendeu inteiramente a Constituição de 1946, nem operou em um vácuo institucional completo, inclusive chegando inicialmente a utilizar a Lei de Segurança Nacional já existente para perseguir dissidentes políticos. ${ }^{49}$ Ou seja, mesmo nos períodos mais autoritários da História brasileira, verifica-se não uma supressão ou suspensão completa da legalidade, mas uma série de rupturas parciais com a ordem jurídica existente, com o intuito de orientá-la em direções politicamente controversas, sob a justificativa da preservação da segurança nacional. ${ }^{50}$

De forma ainda mais pronunciada, a redução de certas liberdades civis para promover a segurança ou enfrentar uma grave crise nacional tem sido objeto de intenso debate acadêmico e político no decorrer da história dos Estados Unidos. Como observou James Comey (2003, p. 403), "it has become part of the drinking water in this country that there has been a trade-off of liberty for security". ${ }^{1}$ Nas últimas décadas, e em especial após os ataques de 11 de setembro de 2001, importantes debates jurídicos nos EUA têm refletido um profundo desacordo sobre quais medidas que visem promover a segurança nacional em detrimento da proteção a outros direitos fundamentais seriam ou não justificadas. Nesse debate, os defensores de liberdades individuais usualmente presumem que a métrica com base na qual direitos individuais e segurança são ponderados está de alguma forma enviesada contra os direitos (GRABER, 2005), ou defendem que, de qualquer forma, os compromissos constitucionais com a liberdade e os demais direitos individuais exigem sacrifícios à capacidade de reação do Estado em épocas de crise (FISS, 2006).

O debate sobre o mérito de políticas combativas adotadas em contextos de insegurança tem enfocado exclusivamente o aparente tradeoff entre direitos individuais e segurança. ${ }^{52}$ Embora essas transformações da ordem jurídica sejam certamente polêmicas, o desacordo a seu respeito é essencialmente normativo: ambos os lados do debate concordam que medidas adotadas em nome da segurança pública ou nacional tendem a reduzir o âmbito de proteção a certos direitos individuais, ainda que discordem quanto ao mérito dessas transformações na ordem jurídica (POSNER, 2006; TUSHNET, 2005; GROSS, 2003). Esse lugar-comum, porém, não é pertinente no caso das políticas adaptativas descritas anteriormente. Com efeito, os argumentos suscitados em prol de medidas adaptativas à violência se afastam da narrativa típica, na medida em que (1) tomam o estado de violência ou insegurança como um dado, sem articular qualquer tentativa de combater ou mitigar o problema 
da insegurança em si e (2) a adaptação proposta consiste basicamente em fortalecer a proteção aos direitos de certas potenciais vítimas, em vez de restringir os direitos de potenciais agressores.

Dessa forma, os argumentos associados a políticas adaptativas apontam em uma direção completamente diferente daquela pressuposta pelas preocupações típicas com direitos fundamentais em tempos de crise: a policy defendida como resposta à insegurança representa um aumento na proteção a certos direitos fundamentais, ainda que $\mathrm{em}$ detrimento de outras policies do Estado e possivelmente prejudicando a promoção de valores constitucionalmente relevantes. ${ }^{53}$ Não obstante o seu caráter de "resignação" diante da violência, esses argumentos podem vir a ter importantes consequências práticas. No item a seguir, serão exploradas algumas das implicações distributivas das chamadas "políticas adaptativas" em uma sociedade desigual como a brasileira.

\section{Perdas públicas, ganhos Privados? Algumas possíveis IMPLICAÇÕES DAS POLÍTICAS ADAPTATIVAS À INSEGURANÇA}

Este trabalho buscou identificar como a situação de insegurança vigente no Brasil tem embasado argumentos capazes de afetar o desenvolvimento do Direito no país sob a forma de políticas adaptativas. Apesar da intensa cobertura da mídia sobre cada um dos casos aqui analisados, as pressões emergentes para a adaptação de diversos ramos do Direito à situação fática de violência ainda não haviam sido identificadas ou teorizadas como um novo padrão ou tendência de evolução jurídica. Com este estudo, buscou-se não somente revelar esse padrão relativamente inconsciente de adaptação do Direito à insegurança, mas também desenvolver algumas ferramentas teóricas para a sua análise.

O debate tradicional sobre a relação entre Direito e insegurança tem abordado incessantemente o risco que políticas combativas à insegurança representam para direitos fundamentais e para o próprio Estado de Direito. Em sentido diverso, as políticas adaptativas aqui identificadas buscam mitigar os efeitos da insegurança por meio de um fortalecimento dos direitos individuais das potenciais vítimas. A questão a ser discutida - e até o momento não explicitamente enfrentada - é quais são os custos jurídicos oriundos dessas adaptações, isto é, quais outras políticas públicas ou valores constitucionalmente relevantes podem estar sendo progressivamente expurgados do Direito nesse processo adaptativo.

É certo que os argumentos baseados em insegurança nem sempre são ou deverão ser vencedores; no caso relativo à divulgação de salários de servidores públicos, por exemplo, o Supremo Tribunal Federal sinalizou que não vai necessariamente aceitar como preponderantes as preocupações sobre segurança arguidas pelas partes. ${ }^{54}$ No entanto, se é verdade que não foram automaticamente vitoriosos, tampouco se pode desconsiderar que esses argumentos têm sido levados a sério na esfera política e, sobretudo, no âmbito judicial. 
O potencial transformador da insegurança sobre o Direito não deveria ser de todo surpreendente, tendo em vista a centralidade do valor "segurança" na ordem jurídica brasileira. No Brasil, a segurança aparece tanto no preâmbulo da Constituição de 1988 como no caput do artigo $5^{\circ}$, dispositivo que abrange a maior parte dos direitos e garantias fundamentais dos brasileiros e estrangeiros no país. ${ }^{55}$ Se nos Estados Unidos costuma-se dizer que a Constituição não pode ser interpretada como um pacto de suicídio ("the Constitution is no suicide pact"), pode-se dizer que os tribunais brasileiros têm evitado atuar como cúmplices de homicídios por aplicar os preceitos jurídicos existentes de forma excessivamente rígida.

Em um cenário jurisprudencial no qual o Supremo Tribunal Federal tem adotado concepções cada vez mais ambiciosas e abrangentes dos efeitos que direitos fundamentais podem ter sobre os mais diversos setores do Direito nacional, 56 é natural que a percepção (ainda que não conte necessariamente com base empírica) de extremo e permanente perigo à segurança dos indivíduos, aliada ao emprego de exames de proporcionalidade, possa afetar de forma profunda a ordem jurídica brasileira. O TJRJ já descreveu o cenário de perigo individual na cidade do Rio de Janeiro como um "fato público e notório"; 57 não se trata de um simples floreio retórico, já que, nos termos do artigo 334 do Código de Processo Civil, "fatos públicos e notórios” independem de prova. ${ }^{58}$ Essa livre construção de imagens "impressionistas" sobre a situação de violência nas grandes cidades do país pode ser incentivada por um Supremo Tribunal Federal que, embora afeito a usar o vocabulário da proporcionalidade, ainda não refletiu de forma sistemática sobre como lidar com as afirmativas empíricas controversas que necessariamente devem ser discutidas nesse tipo de exame. ${ }^{59}$ Consequentemente, o resultado de exames de proporcionalidade pode vir a ser injustificadamente enviesado no sentido de favorecer políticas adaptativas, em detrimento da promoção de outros valores constitucionais relevantes como a transparência.

Não se pretende sugerir aqui que políticas adaptativas são sempre injustificáveis. Pelo contrário, elas podem ser perfeitamente ser razoáveis dentro de certas circunstâncias. ${ }^{60}$ Ainda assim, os argumentos baseados em segurança não devem ser aceitos de forma automática e sem maior reflexão tão somente pelo fato de envolverem um aumento na proteção a direitos individuais. Uma tradicional preocupação de juristas comprometidos com o respeito ao Estado de Direito em momentos de insegurança pública tem sido a de que o medo generalizado possa prejudicar nossa capacidade de tomar decisões políticas consistentes e empiricamente justificadas. Contudo, não parecer haver razão para restringir esse tipo de crítica à esfera das políticas combativas. Os efeitos negativos do medo sobre a nossa capacidade de realizar tradeoffs que envolvem medidas de promoção de segurança estão igualmente presentes no caso das políticas adaptativas. 61

Essa preocupação é especialmente válida se considerarmos que, da mesma forma que as políticas combativas tendem a impor custos de maneira não uniforme sobre a 
sociedade, atingindo de forma desigual os direitos de grupos mais suscetíveis de serem percebidos como potenciais agressores, os custos e benefícios das políticas adaptativas emergentes no Brasil de hoje também incidem de forma desproporcional na população. Em outros países, o risco de ameaças terroristas atua de forma relativamente difusa sobre a sociedade, afetando, em tese, os seus mais diversos setores. No Brasil, embora as camadas mais pobres sejam as maiores vítimas da violência, as políticas adaptativas descritas neste trabalho visam invariavelmente proteger setores privilegiados da sociedade. A perda de transparência nos casos discutidos acima tende a impor custos difusos, arcados pela sociedade como um todo e dificilmente perceptíveis no âmbito individual. Os seus benefícios, porém, são claramente concentrados em determinados grupos - servidores públicos com "supersalários", motoristas em grandes cidades, altos executivos e o alto escalão do Poder Executivo -, os quais dificilmente poderiam ser considerados representativos da maioria da população brasileira. Sendo o benefício da transparência difuso e os seus custos concentrados, não é de surpreender que esses grupos tenham conseguido se mobilizar em prol de uma transformação do Direito vigente em seu benefício. ${ }^{62}$

Nesse cenário, cumpre investigar se e como os setores conservadores da sociedade brasileira têm apoiado tanto medidas combativas quanto medidas adaptativas à violência, ainda que aquelas priorizem políticas públicas sobre interesses individuais e estas apresentem estrutura diametralmente oposta, privilegiando direitos individuais sobre políticas públicas. Nos Estados Unidos, o mesmo partido político que defende medidas rigorosas contra o terrorismo propugna o direito individual de carregar armas, agora constitucionalmente reconhecido. ${ }^{63}$ No Brasil, de forma semelhante, a derrota da Lei do Desarmamento, que traria significativo potencial para salvar vidas, quando submetida a referendo popular em 2005, foi atribuída sobretudo às preocupações da população com a falta de segurança pública no país. ${ }^{64} \mathrm{Com}$ efeito, as elites brasileiras têm lançado mão de argumentos de segurança simultaneamente como espada e escudo: espada, no caso de políticas combativas, que propugnam maiores obrigações e menores direitos aos acusados ou suspeitos da prática de crimes violentos; e escudo, no caso de políticas adaptativas, que reduzam as obrigações e fortaleçam os direitos individuais dos membros das elites na condição de potenciais vítimas da violência .

Diante de suas possíveis implicações distributivas, as políticas adaptativas à insegurança devem ser submetidas a um escrutínio mais severo do que tem sido exercido até hoje. Caso contrário, corre-se o risco de que argumentos com base na situação de insegurança sejam crescentemente empregados de forma exagerada e meramente pretextual. Não cabe aqui avaliar de forma definitiva todas as questões suscitadas e os balanceamentos exigidos pelos diversos casos examinados. Pretendeu-se mostrar apenas que essas questões, até então despercebidas, merecem fazer parte do debate sobre Direito e insegurança no Brasil. 
Qualquer análise econômica de políticas criminais leva em consideração tanto os custos do crime em si como os custos associados à investigação e punição criminal. Buscou-se demonstrar que os custos diretos da violência e de sua repressão apresentam um paralelo no mundo do Direito. Todavia, enquanto os custos de políticas combativas à insegurança há muito integram o debate sobre o tema, os custos potencialmente decorrentes de políticas adaptativas no Brasil têm sido ignorados e, por conseguinte, excluídos da equação. Sugeriu-se aqui que a crescente opacidade da sociedade brasileira oriunda da crescente adoção de políticas adaptativas dificulta a atuação de mecanismos de accountability com relação às elites e pode vir a retardar o desenvolvimento do país e a própria superação das causas econômicas e sociais da violência.

: ARTIGO APROVADO (15/05/2013) : RECEBIDO EM 06/04/2012

\section{NOTAS}

* Versões anteriores deste trabalho foram apresentadas no Seminario en Latinoamérica de Teoría Constitucional y Política (SELA) sobre o tema "Insecurity, Democracy, and Law", realizado em junho de 2010 em Santiago, Chile, e no Seminário de Pesquisadores da FGV Direito Rio, em julho de 2010. Os autores gostariam de agradecer aos participantes de ambos os eventos pelos comentários, bem como a George Georgiev e Mario Grandchamp, pela leitura detalhada de uma versão anterior deste trabalho e pelas excelentes sugestões. Todos os erros são exclusivamente nossos.

1 Estamos cientes de que nem todos os crimes computados em índices de criminalidade seriam necessariamente considerados "violentos" (por exemplo, corrupção ativa, prevaricação, furto). Além disso, existem formas de violência que, na melhor das hipóteses, seriam imperfeitamente captadas por esse tipo de levantamento quantitativo (por exemplo, ações sutis, mas sistemáticas de agentes do Estado no sentido de intimidar certas minorias étnicas, políticas etc.). Apesar disso, parece seguro utilizar índices de criminalidade como um bom proxy para um tipo importante de violência contra um conjunto importante de direitos individuais, como integridade física, liberdade sexual, liberdade de locomoção e propriedade.

2 São frequentes na literatura os argumentos de que o incremento no poder repressivo do Estado, ainda que justificado em contextos de insegurança, pode (a) pavimentar o caminho para uma repressão ainda mais intensa e injustificável (argumento da "rampa escorregadia", ou slippery slope) ou (b) criar um estado de coisas no qual será muito custoso repudiar tais medidas repressivas mesmo após o fim da situação de insegurança (o chamado ratchet effect). Para uma discussão desses dois argumentos, ver Gross (2003) e Posner; Vermeule (2005).

3 A inexigibilidade de deveres jurídicos em face de situações de insegurança e extremo risco à vida é, sem dúvida, fenômeno tradicional no âmbito do Direito. As violações até mesmo dos mais fundamentais deveres jurídicos, como a obrigação de não matar, tornam-se não puníveis em face de risco real e iminente à vida capaz de qualificar a conduta como legítima defesa.

4 Constituição da República Federativa do Brasil, art. 37. 
5 Ver, por exemplo, a Lei n. 6.385/76, art. $3^{\circ}$, VI.

6 Nos últimos anos, tem-se observado um movimento crescente de repúdio a melhores práticas (best practices) institucionais como forma de incentivar o crescimento econômico de países em desenvolvimento em prol de instituições second-best, as quais seriam mais bem adaptadas à realidade desses países (RODRIK, 2008).

7 Soares; Naritomi (2010) argumentam que o nível de ocorrências criminais na América Latina, embora extremamente elevado, não é muito diferente do que seria previsto tendo em vista as desigualdades sociais e as taxas de investimento em policiamento e prisões na região. Logo, é razoável supor que, por sua vez, o desenvolvimento econômico e a redução das desigualdades sociais conduziriam a uma redução dos níveis de violência.

8 No Brasil do século XIX e início do século XX, pelo contrário, diversas sociedades anônimas estipulavam os salários dos seus principais executivos em seus estatutos, os quais, por sua vez, eram publicados nos principais jornais locais (PARGENDLER, 2012).

9 Idem (observando que a própria CVM admite a relevância da questão da segurança).

10 A Instrução exige, ainda, informações detalhadas com relação à política e à forma de remuneração adotadas pela companhia.

11 Segundo um levantamento recente, embora as dez companhias mais negociadas no Brasil em 2008 tenham despendido R \$ 1,2 bilhão com executivos e conselheiros, somente uma - o Banco do Brasil, uma sociedade de economia mista controlada pelo Governo Federal - divulgava o salário pago ao seu principal executivo (PERES, 2009).

125 Vara Federal do Rio de Janeiro, Ação de Procedimento Ordinário n. 2010.5101002888-5. Decisão de 2 de março de 2010. A liminar foi posteriormente mantida pelo Superior Tribunal de Justiça. Cf. a decisão monocrática proferida pelo Ministro Cesar Asfor Rocha em 15 de abril de 2010 na Suspensão de Liminar e de Sentença n. 1.210/RJ. No entendimento do Ministro, a CVM "não demonstra que a ausência de divulgação imediata do 'valor da maior remuneração individual', do 'valor da menor remuneração individual' e do 'valor médio de remuneração individual' (fl. 809) possa causar grave, iminente e irreparável lesão à ordem, à economia e ao interesse públicos, o que torna inviável a utilização da suspensão de liminar e de sentença”. A decisão de suspender a eficácia da Instrução n. 480 foi mantida em decisão monocrática subsequente, proferida pelo Ministro Castro Meira na MC m. 17.350/RJ, julgada em 7 de outubro de 2010 .

135 Vara Federal do Rio de Janeiro, Ação de Procedimento Ordinário n. 2010.5101002888-5. Sentença de 17 de maio de 2013.

14 Ver, por exemplo, Krugman (2002), descrevendo o crescimento dos salários dos principais executivos nos Estados Unidos de 39 vezes a mais de 1.000 vezes o de um trabalhador médio. De acordo com Krugman, "[t]he explosion in C.E.O. pay over the past 30 years is an amazing story in its own right, and an important one. But it is only the most spectacular indicator of a broader story, the reconcentration of income and wealth in the U.S."

15 Disponível em: <http://deolhonascontas.prefeitura.sp.gov.br/index.htm>. Acesso em: 30 nov. 2011.

16 Havia cerca de 147 mil servidores na administração direta e 15 mil na indireta. Segundo a Prefeitura, os nomes e salários dos membros da GCM não foram divulgados por questões de segurança.

17 Ver nota "Portal possibilita fiscalização dos atos da Prefeitura", 17 de junho de 2009, disponível no site da Prefeitura de São Paulo: <http://www.prefeitura.sp.gov.br/portal/a_cidade/noticias/index.php?p=30271>. Acesso em: 30 nov. 2011.

18 Informações prestadas pela Prefeitura da Cidade de São Paulo na Suspensão de Segurança (SS) n. 3.902 e reproduzidas na decisão monocrática do Ministro Gilmar Mendes em 9 de julho de 2009.

19 “Site com salários de servidores municipais tem 70 mil acessos em um dia”, Globo.com/G1, 18 de junho de 2010, disponível em: <http://g1.globo.com/Noticias/SaoPaulo/0,,MUL1198680-5605,00-SITE+COM+SALARIOS+ DE+SERVIDORES+MUNICIPAIS+TEM+MIL+ACESSOS+EM+UM+DIA.html>. Acesso em: 30 nov. 2011. 
20 Ver, por exemplo, as reportagens "Prefeitura paga até R \$ 143 mil a servidor", Jornal da Tarde, 17 de junho de 2009; "Divulgação de salários pela Prefeitura de SP é legal, mas mal usada, dizem especialistas”, Último Segundo, 17 de junho de 2009, disponível em: <http://ultimosegundo.ig.com.br/brasil/2009/06/17/divulgacao+dos+salarios + e+legal+mas+esta+sendo+mal+usada+dizem+especialistas++6787907.html . Acesso em: 30 nov. 2011.

21 Por exemplo, Oded Grajew, coordenador do Movimento Nossa São Paulo, declarou à agência de notícias G1 que "a gestão pública é diferente porque eles têm salários pagos por cada um de nós" e "a população é acionista da prefeitura e tem o direito de saber o que é feito com seu dinheiro. Estar na administração pública tem ônus e bônus. Quem trabalha no serviço público deve prestar contas à sociedade" ("Lista de salários na internet causa polêmica na Prefeitura de SP", G1, 17 de junho de 2009, disponível em: <http://g1.globo.com/Noticias/SaoPaulo/0,,MUL1197090-5605,00-LISTA+DE+ SALARIOS+NA+INTERNET+CAUSA+POLEMICA+NA+PREFEITURA+DE+SP.html>. Acesso em: 30 nov. 2011).

22 Citado na reportagem "Servidores criticam divulgação de salários na Internet", Folha Online, 17 de junho de 2009, disponível em: <http://www1.folha.uol.com.br/folha/cotidiano/ult95u582178.shtml>. Acesso em: 30 nov. 2011.

23 Citado na reportagem "Lista de salários na internet causa polêmica na Prefeitura de SP", G1, 17 de junho de 2009 .

24 Citado na reportagem "Kassab divulga salários e servidores vão à Justiça", Último Segundo / Agência Estado, 17 de junho de 2009, disponível em: <http://ultimosegundo.ig.com.br/brasil/2009/06/17/kassab+divulga+vencimentos+ e+servidores+vao+a+justica+6775903.html>. Acesso em: 30 nov. 2011.

25 Citado na reportagem "Divulgação de salários pela Prefeitura de SP é legal, mas mal usada, dizem especialistas”, Último Segundo, 17 de junho de 2009, disponível em: <http://ultimosegundo.ig.com.br/brasil/ 2009/06/17/divulgacao+dos+salarios $+\mathrm{e}+$ legal +mas + esta + sendo + mal+usada + dizem + especialistas $++6787907 . \mathrm{h}$ tml>. Acesso em: 30 nov. 2011.

26 Trecho reproduzido no relatório da decisão do Ministro Gilmar Mendes na Suspensão de Segurança n. 3.902, decidida em 9 de julho de 2009.

27 Ver, em especial, o art. 39, § 6 ${ }^{\circ}$, da Constituição Federal (“Os Poderes Executivo, Legislativo e Judiciário publicarão anualmente os valores do subsídio e da remuneração dos cargos e empregos públicos”).

28 Decisão Monocrática do Min. Gilmar Mendes na Suspensão de Segurança n. 3.902, de 8 de julho de 2009.

29 Para a estrutura típica de exames de proporcionalidade na jurisprudência de vários tribunais ao redor do mundo, ver Sweet; Mathews (2008); Grimm (2007). Vale notar que o Ministro Gilmar Mendes tem sido um dos mais entusiásticos defensores da aplicação do exame de proporcionalidade na solução de conflitos entre princípios da Constituição brasileira, mesmo antes de sua indicação para o STF. Ver, por exemplo, Mendes (1999).

30 Decisão Monocrática do Min. Gilmar Mendes na Suspensão de Segurança n. 3.902, de 9 de julho de 2009.

31 Voto do Min. Carlos Ayres Britto no Segundo Agravo Regimental na Suspensão de Segurança n. 3.902/SP, julgado em 9 de junho de 2011.

32 Em outubro de 2011, o Supremo Tribunal Federal reconheceu “repercussão geral” no Recurso Extraordinário com Agravo (ARE n. 652.777). Este recurso foi interposto pelo Município de São Paulo contra uma decisão do TJSP que havia concedido a uma servidora pública municipal o direito de ter seu nome e as informações relativas aos seus vencimentos excluídos do site "De Olho nas Contas". Provavelmente, será no julgamento deste caso que o STF se pronunciará em definitivo sobre o tema.

33 Idem.

** Nota do editor: Insufilm, usado aqui como sinônimo de película.

34 Ver, por exemplo, a crítica à obrigatoriedade de se parar no sinal vermelho à noite e em locais perigosos contida no recente editorial "Mais um alerta para a segurança do Brasiliense". Correio Braziliense, 31 de outubro de 
2010: “A legislação existe para proteger o cidadão. Quando não cumpre tal função, perde a finalidade. Ninguém pode ser obrigado a se expor ao perigo".

35 Ver, por exemplo, a Lei Municipal de Porto Alegre n. 8.956, de 18 de julho de 2002, a qual dispõe, em seu art. $1^{\circ}$, que "[o]s semáforos localizados nos pontos de risco da Capital, assim considerados pelas autoridades competentes, poderão permanecer com o sinal luminoso amarelo intermitente no período noturno”. Uma proposta semelhante - o Projeto de Lei Municipal n. 333/2009 - está tramitando na Câmara de Vereadores do Rio de Janeiro; na justificativa do Projeto, o Vereador Cristiano Girão observa o seguinte: "O Presente Projeto de Lei tem o objetivo de conferir aos motoristas do Município uma maior segurança no período noturno, pois é sabido que em locais pertos de pardais e de lombadas eletrônicas são alvos de diversos assaltos, haja vista a diminuição de velocidade dos veículos”.

36 Art. $1^{\circ}$ da Lei n. 4.892, promulgada em 10 de setembro de 2008.

37 Ver, por exemplo, a reportagem "Multa por avanço de sinal aplicada a motorista é cancelada," Portal G1, de 5 de março de 2009, disponível em: <http://g1.globo.com/Noticias/Rio/0,, MRP1030818-5606,00.html>. Acesso em: 30 nov. 2011.

$3817^{\text {a }}$ Câmara Cível do TJRJ, Apelação Cível n. 2008.001.66289, Rel. Des. Elton Leme, julgada em 4 de março de 2010 .

39 Idem. Na verdade, esta caracterização judicial do Rio de Janeiro como uma cidade extremamente violenta em decisões não é novidade. Por exemplo, em 1993, no julgamento da Apelação Cível n. 1993.001.00554, em 13 de abril de 1993, a 6 a Câmara Cível afirmou em acórdão escrito pelo Des. Sérgio Cavalieri que "Em face da violência urbana, onde acintosos delinquentes de armas em punho e em plena luz do dia, invadem os lares para roubar, estuprar e matar, a todos atemorizando e enchendo de insegurança, o gradeamento do prédio, longe de ter o caráter meramente estético ou embelezador, constitui benfeitoria necessária à segurança dos seus moradores”. Em 1994, em acórdão do Des. Carlos Alberto Direito, o TJRJ entendeu que a responsabilidade civil do Estado por atos de policiais, no estrito cumprimento do dever legal, deveria ser interpretada levando-se em conta "[o] momento em que vive a sociedade brasileira, particularmente nas grandes cidades, de insegurança e grave desordem social e econômica" (Apelação Cível n. 1993.001.06102, 1ª Câmara Cível, julgado em 17 de maio de 1994). De fato, desde 1988, as decisões do TJRJ explicitamente consideravam "as condições resultantes do alto grau de insegurança que ora se verifica [na cidade do Rio de Janeiro]” (acórdão do Des. Paulo Pinto na Apelação Cível n. 1988.001.04130, $3^{a}$ Câmara Cível, julgado em 12 de dezembro de 1988).

40 Trata-se de um risco reconhecido pelo próprio representante da BHTRANS, no documento já citado, em que se recomenda a adoção do sinal intermitente: "Cada implantação de amarelo piscante deverá ser acompanhada do levantamento do índice de acidentes na interseção dos anos anteriores, no horário que será implantado o amarelo piscante, para o acompanhamento da situação antes e depois da implantação da medida. Ao final de um período de 6 a 12 meses, deve ser feita uma avaliação comparativa e as correções necessárias. Caso haja aumento do índice de acidentes em uma determinada interseção com o amarelo piscante em operação, esse deverá ser retirado" (PINTO JÚNIOR, 2007, p. 10).

41 Ver, por exemplo, o caso de Maringá, município que experimentou um crescimento de 65\% no número de acidentes após a introdução de sinais amarelos piscantes devido ao risco de assalto, os quais foram, desde então, abandonados em prol da sinalização convencional (O DIÁRIO DO NORTE DO PARANÁ, 2008).

42 Cf., por exemplo, a jurisprudência do TJRJ no sentido de que o corte do fornecimento de energia elétrica enseja indenização por dano moral porque, entre outros constrangimentos, expõe o consumidor à insegurança da cidade (por exemplo, a Apelação Cível n. 2008.8.19.0021, 2ª Câmara Cível, Rel. Des. Cristina Tereza Gaulia, julgado em 26 de janeiro de 2010).

43 Para uma comparação entre os diferentes tipos de “direito autoritário" nos países do Cone Sul, ver Pereira (2005). Sobre a experiência específica dos EUA, ver Donohue (2008); Farber (2008).

44 Exemplos historicamente típicos de transformações jurídicas em face de situações emergenciais, entre outras respostas, o aumento dos poderes disponíveis aos órgãos do Estado considerados mais capazes de responder à emergência de forma decisiva e eficaz - tipicamente, o Poder Executivo e as Forças Armadas; a adoção de medidas 
repressivas drásticas, como o isolamento de indivíduos considerados perigosos ou o uso de tortura em interrogatórios; a diminuição do escopo da apreciação judicial sobre medidas emergenciais consideradas necessárias, como, por exemplo, a detenção preventiva de potenciais agressores.

45 Por exemplo, Vargas jamais convocou o plebiscito exigido e regulado pelos arts. 175 a 187 da Constituição de 1937 para que a Constituição permanecesse válida após o fim do seu primeiro mandato como Presidente.

46 Para citar somente alguns exemplos, ver o art. 168 da referida Constituição, que autoriza o Presidente, entre outras prerrogativas, a promover a censura de correspondência e a suspender a liberdade de reunião. Vale lembrar que o art. 186 fechava o texto constitucional ativando imediatamente todos esses e outros poderes presidenciais, ao dispor: "É declarado em todo o país o estado de emergência".

47 Segundo o preâmbulo da Constituição de 1937, o objetivo principal daquela carta constitucional e do golpe de estado era o de, "[a]tendendo às legitimas aspirações do povo brasileiro à paz política e social, profundamente perturbada por conhecidos fatores de desordem [...] assegurar à Nação a sua unidade, o respeito à sua honra e à sua independência, e ao povo brasileiro, sob um regime de paz política e social, as condições necessárias à sua segurança, ao seu bem-estar e à sua prosperidade”.

48 Lei n. 38, de 4 de abril de 1935.

49 Ibidem, p. 68 e o capítulo III em geral. Os diversos atos institucionais promulgados durante o regime militar representaram instrumentos extraconstitucionais de restrição temporária de diversos direitos individuais e foram invariavelmente justificados com base em argumentos de segurança. O preâmbulo do AI-1, por exemplo, que cassou os direitos políticos de mais de 500 cidadãos, explicava que, tendo em vista a ameaça de grave instabilidade social por grupos "subversivos", as novas medidas justificavam-se para preservar "a ordem, a segurança, a tranquilidade, o desenvolvimento econômico e cultural e a harmonia política e social do País comprometidos por processos subversivos e de guerra revolucionária”. Os Atos Institucionais n. 2 e 5, também justificados com base na "segurança nacional" e na "manutenção da ordem", igualmente transformaram a legislação no sentido de restringir os direitos individuais dos cidadãos e ampliar ainda mais os poderes repressivos do Poder Executivo.

50 Nesse sentido, aliás, em termos do resultado que atingem mudança no direito vigente, períodos de emergência não são qualitivamente diferentes de outros momentos mais "calmos" na história de um país. A diferença parece ser de grau. Como observa Tushnet, "it is not, then, that law is silent during wartime. Rather, it is that sometimes it speaks in tones that advocates of particular positions do not like. But, after all, how is that different from any other time?" (2005, p. 42-43).

51 Cf. também LINFELD (1990, p. 169) (“[t]he stated justification for virtually every violation of civil liberties has been "national security"). Recentemente, Ronald Dworkin observou que "[p]eople's respect for human and civil rights is very often fragile when they are frightened, and Americans are very frightened" (DWORKIN, 2002). Essa ideia de que há um tradeoff entre segurança e certos direitos fundamentais, bem como o vocabulário de "sopesamento" ou "balanceamento" que a acompanha, está disseminada transversalmente ao espectro ideológico, como observado por Jeremy Waldron: "We hear talk of a balance between security and liberty from all sides. We hear it from conservatives [...]; from liberals [...]; and from almost everyone in between” (2006, p. 455). Foi essa mesma preocupação que levou o Justice Thurgood Marshall a observar que "[h]istory teaches that grave threats to liberty often come in times of urgency, when constitutional rights seem too extravagant to endure" (Skinner v. Railway Labor Executives Association, 489 U.S. 602, 1989; Marshall, J., voto vencido). No mesmo sentido, a Justice Sandra Day O'Connor afirmou que "[i]t can never be too often stated that the greatest threats to our constitutional freedoms come in times of crisis" (Vernonia School District v. Wayne Acton, 515 U.S. 646, 1995; O'Connor, J, voto vencido).

52 É certo que há complexidades e nuances no debate acadêmico nos EUA que não serão aqui examinadas. Discute-se, por exemplo, em que medida faz sentido falar de um tradeoff entre segurança e direitos, diante do reconhecimento que um mínimo de segurança é pré-condição para o exercício de quaisquer direitos. Ver, por exemplo, Dinh (2002, p. 400) ("the dichotomy between freedom and security is not new, but it is false"; "security is the very precondition of freedom”). Para uma discussão desse argumento, ver Waldron (2009). Apesar de reconhecermos a existência dessas questões em aberto, parece-nos plausível dizer que, no geral, a imagem que prevalece tanto no debate público quanto na academia continua sendo de um tradeoff entre segurança e direitos ao menos no curto prazo - isto é, mesmo se o objetivo de longo prazo de políticas de promoção de segurança seja a 
proteção de direitos, no curto prazo essas políticas tendem a ser encaradas como restritivas do escopo de certos direitos e liberdades.

53 Essa possibilidade de transformação jurídica aparentemente contraintuitiva, porém, não passou completamente despercebida. Mark Graber observou que as narrativas canônicas nos Estados Unidos “omit numerous instances in which military conflict inspired some government officials to increase protections for civil rights and liberties" (2005, p. 96). Os exemplos principais elencados por Graber incluem a proteção, pela Suprema Corte, da liberdade religiosa de Testemunhas de Jeová que se recusavam a saudar a bandeira dos Estados Unidos, a expansão da igualdade racial durante a Guerra Civil e a expansão dos direitos dos trabalhadores norte-americanos durante a $1^{\mathrm{a}}$ Guerra Mundial. Nenhuma das duas hipóteses elencadas por Graber, porém, confunde-se com as políticas adaptativas emergentes no Brasil, as quais buscam simplesmente adaptar a ordem jurídica a uma situação de insegurança, sem combater as suas causas.

\section{Ver item 1.2 supra.}

55 Constituição da República Federativa do Brasil, preâmbulo (segundo o qual a Constituição busca "instituir um Estado Democrático, destinado a assegurar o exercício dos direitos sociais e individuais, a liberdade, a segurança, o bem-estar, o desenvolvimento, a igualdade e a justiça como valores supremos de uma sociedade fraterna, pluralista e sem preconceitos, fundada na harmonia social e comprometida, na ordem interna e internacional, com a solução pacífica das controvérsias" - grifamos) e art. 5, caput ("[t]odos são iguais perante a lei, sem distinção de qualquer natureza, garantindo-se aos brasileiros e aos estrangeiros residentes no País a inviolabilidade do direito à vida, à liberdade, à igualdade, à segurança e à propriedade" - grifamos).

56 Ver, por exemplo, a posição do STF sobre a "eficácia objetiva” dos direitos fundamentais e o seu possível efeito horizontal (isto é, nas relações entre particulares, e não apenas entre particulares e o Estado), expressa, por exemplo, no Recurso Extraordinário n. 201.819/RJ, julgado em 11 de outubro de 2005, DJ 27/10/2006, em que o STF decidiu que uma sociedade civil sem fins lucrativos - a União Brasileira de Compositores - não poderia expulsar um dos associados dos seus quadros sem lhe garantir um mínimo de "devido processo legal", por força do direito constitucional à ampla defesa).

57 Cf. nota 40 supra. Outro exemplo de decisão judicial que descreve a situação de violência no Rio como um "fato público e notório" pode ser encontrado no Recurso Cível n. 2009.700.059332-1 (4ª Câmara Recursal, decidido em 9 de setembro de 2009), afirmando que “a violência na cidade [do Rio de Janeiro] é um fato público e notório".

58 Art. 334 do CPC: “Não dependem de prova os fatos: I - notórios; [...]".

59 Sobre a natureza empírica dos juízos subjacentes às análises de adequação e necessidade no exame de proporcionalidade, cf. Schuartz (2005). Para uma análise crítica da consistência do STF no emprego de exames de proporcionalidade, cf. Ávila (2010) e Silva (2002).

60 Uma maneira alternativa de se levar a sério o direito constitucional à segurança, mas evitando-se as distorções e os problemas mencionados neste trabalho, seria utilizar ou desenvolver mecanismos processuais que permitissem ao Judiciário atuar sobre a insegurança sem uma ênfase excessiva ou exclusiva na perspectiva de um direito individual à segurança. Argumentos baseados em insegurança feitos por moradores de áreas específicas, por exemplo, poderiam embasar procedimentos judiciais de caráter coletivo, com vistas a monitorar se e como o estado adota e implementa políticas públicas de segurança naquela comunidade. Nesse cenário, o objetivo judicial seria o de garantir a adoção de medidas que promovam a segurança geral naquela comunidade, e não resolver insatisfações específicas de indivíduos que percebam a sua situação pessoal como excessivamente "insegura". A atuação judicial seria parte de um diálogo mais amplo - e mais empiricamente informado - entre cidadãos e poderes públicos sobre cenários de insegurança que impedem a realização de fins constitucionais. Evidentemente, uma estratégia desse tipo dependeria da disponibilidade dos recursos processuais adequados no direito positivo brasileiro. Ainda assim, é importante notar que as regras processuais existentes não devem nos levar a crer que é conceitual e institucionalmente impossível integrar o direito à segurança na atuação judicial de uma forma que não seja puramente individual. Agradecemos a Owen Fiss por nos chamar a atenção para essa possibilidade.

61 Um recente exemplo de como o efetivo nível de violência e criminalidade em uma dada comunidade não está necessariamente correlacionado com as percepções individuais de (in)segurança pode ser encontrado no Índice de 
Percepção da Presença do Estado, elaborado pela FGV-RJ sob a coordenação de Marcelo Simas e Fernando de Holanda Barbosa e divulgado em junho de 2010. Os pesquisadores realizaram surveys em algumas das áreas com menor criminalidade do Rio de Janeiro, de um lado, e das áreas com maior criminalidade, de outro, pedindo aos moradores entrevistados que dessem uma "nota" para o grau de liberdade de ir e vir e de proteção à sua integridade física que sentiam possuir naquela área. As "notas" dadas pelos moradores de áreas mais seguras, em geral de classes mais altas, nesses dois aspectos foram consistentemente mais baixas que aquelas dadas pelos moradores de favelas que estavam incluídas na amostra. Um sumário dos principais resultados do estudo pode ser encontrado no site disponível em: <http://www.oglobo.com.br/rio/arquivos/apresentacao_cidadania.ppt>. Uma breve discussão da repercussão do estudo entre especialistas em segurança pública pode ser encontrada na reportagem "Para especialistas, pesquisa comprova que população se sente mais segura na área onde vive”, publicada no Globo Online em 7 de julho de 2010. Disponível em: <http://oglobo.globo.com/rio/mat/2010/06/07/para-especialistas-pesquisa-comprova-quepopulacao-se-sente-mais-segura-na-area-onde-vive-916810971.asp >. Acesso em: 30 nov. 2011.

62 Mais ainda, é possível que, em um cenário dominado por políticas adaptativas, haja menos incentivos para que essas elites façam pressão política pela adoção de medidas que promovam a segurança em geral. Afinal, com políticas adaptativas perfeitas, a segurança dos integrantes desses grupos estaria cada vez menos vinculada às variáveis que determinam o nível de segurança da comunidade como um todo.

\section{District of Columbia v. Heller, 128 S. Ct. 2783 (2008).}

64 A Lei n. 10.826/2003 proibia, em seu art. 35, "a comercialização de armas de fogo e munição em todo o território nacional”, salvo em alguns casos excepcionais. O mesmo artigo, porém, dispunha em seu $\S 1^{\circ}$ que a entrada em vigor desta proibição dependia de aprovação popular em referendo a ser realizado em outubro de 2005. O movimento pró-desarmamento sofreu uma estrondosa derrota na urnas: 63,94\% dos votos válidos se opuseram à proibição, e apenas 36,06\% concordaram com a regra do art. 35 . No geral, considera-se que, entre os trunfos da campanha antidesarmamento, estava o apelo à percepção, por parte das pessoas de classe média e média-alta, de que a posse de arma em casa é um substituto necessário à falha do Estado em proteger o direito à segurança.

\section{REFERÊNCIAS BIBLIOGRÁFICAS}

AGÊNCIA SENADO. Dornelles critica regras da CVM, 9 de março de 2010.

ALVES, Francisco Edson. Medo da violência aumenta multas. O Dia Online, 7 de março de 2009.

ÁVILA, Humberto B. Teoria dos princípios. 11. ed. rev. São Paulo: Malheiros, 2010.

BARAK, Aharon. Foreword: a judge on judging: the role of a Supreme Court in a democracy. Harvard Law Review, n. 116, p. 16-162, 2003.

BRANDEIS, Louis D. Other people's money, and how the bankers use it. New York: A. Stokes Co., 1914.

BRANDON, Mark E. War and the American constitutional order. In: TUSHNET, Mark (Ed.). The Constitution in wartime: beyond alarmism and complacency. Durham: Duke University Press, 2005.

CARVALHO, Jailton de; WEBER, Demétrio. Uso de película insulfilm no vidro dos carros tem novas regras e aparelho de medição. O Globo, 22 de novembro de 2007.

CASTANHEIRA, Joaquim. Ele decidiu revelar o próprio salário: a decisão inédita da Usiminas. IstoÉ Dinheiro, 20 de abril de 2009.

CERQUeIRA, Daniel R. C.; CARVAlHO, Alexandre; LOBAO, Waldir J. A.; RODRIGUES, Rute I. Análise dos custos e consequências da violência no Brasil. Texto para Discussao n. 1.284. Brasilia: IPEA, 2007.

COMEY, James B. Terrorism and preserving civil liberties. University of Richmond Law Review, n. 40, p. 403$418,2003$.

DINH, Viet D. Foreword: freedom and security after September 11. Harvard Journal of Law and Public Policy, n. 25, p. 399-406, 2002.

DONOHUE, Laura K. The cost of counterterrorism. Cambridge; New York: Cambridge University Press, 2008. DWORKIN, Ronald. The threat to patriotism. New York Review of Books, fevereiro de 2002.

FARBER, Daniel (Org.). Security v. liberty. New York: Russell Sage Foundation, 2008.

FISS, Owen. The war against terrorism and the rule of law. Oxford Journal of Legal Studies, n. 26, p. 235-256, 2006. FOLHA DE S. PAULO. Até 15\% da frota do país usa insulfilm, 26 de dezembro de 2003. 
GILSON, Ronald J.; HANSMANN, Henry; PARGENDLER, Mariana. Regulatory dualism as a development strategy: corporate reform in Brazil, the U.S. and the EU. Stanford Law Review, n. 63, 2011.

GRABER, Mark. Maintaining and Expanding Civil Liberties in Wartime. In: TUSHNET, Mark (Ed.). The Constitution in wartime: beyond alarmism and complacency. Durham: Duke University Press, 2005.

GRIMM, Dieter. Proportionality in Canadian and German constitutional jurisprudence. University of Toronto Law Journal, p. 383-397, 2007.

GROSS, Oren. Chaos and rules: should responses to violent crises always be constitutional? Yale Law Journal, n. 112, p. 1011-1134, 2003.

KAHN, Tulio. Os custos da violência: quanto se gasta ou se deixa de ganhar por causa do crime no Estado de São Paulo. São Paulo em Perspectiva, n. 13, v. 4, p. 42-48, 1999.

KING, Robert G.; LEVINE, Ross. Finance and growth: Schumpeter might be right. Quarterly Journal of Economics, n. 108, p. 717-37, 1993.

KRUGMAN, Paul Krugman. For richer. New York Times Magazine, 20 de outubro de 2002.

LINFELD, Michael. Freedom under fire. Boston: South End Press, 1990.

LUIZ, Edson; TORRES, Izabelle. Gastos do Planalto com cartões corporativos aumentaram quase $10 \%$ este ano. Correio Braziliense, 27 de outubro de 2009.

MEDEIROS, Vinicius. Nova norma pode exigir divulgação detalhada dos salários dos altos executivos. Jornal do Commercio, 10 de fevereiro de 2009.

MENDES, Gilmar Ferreira. Direitos fundamentais e controle de constitucionalidade. 2. ed. rev. e ampl. São Paulo: Instituto Brasileiro de Direito Constitucional, 1999.

O DIÁRIO DO NORTE DO PARANÁ. Sinal amarelo piscante aumenta acidentes e semáforos voltam a ser acionados, 12 de novembro de 2008.

PARGENDLER, Mariana. Cinco mitos sobre a história das sociedades anônimas no Brasil. In: KUYVEN, Luiz Fernando Martins (Org.). Temas Essenciais de Direito Empresarial - Estudos em Homenagem a Modesto Carvalhosa. São Paulo: Saraiva, 2012.

PEREIRA, Anthony W. Political (in)justice: authoritarianism and the rule of law in Brazil, Chile and Argentina. Pittsburgh: University of Pittsburgh Press, 2005.

PERES, Leandra. Empresas pagam R\$ 1,2 bilhão a executivos. Folha de São Paulo, 6 de abril de 2009.

PINTO JÚNIOR, José Maurício. Proposta de medidas e critérios para adequação da sinalização semafórica nos períodos noturno e de tráfego reduzido. Disponível em:

<http://www.sinaldetransito.com.br/artigos/semaforo_de_madrugada.pdf> (2007).

POSNER, Eric; VERMEULE, Adrian. Acommodating emergencies. In: TUSHNET, Mark (Ed.). The Constitution in wartime: beyond alarmism and complacency. Durham: Duke University Press, 2005.

POSNER, Richard. Not a suicide pact: the constitution in a time of national emergency. New York: Oxford University Press, 2006.

PRILLAMAN, Walter C. Prillaman, crime, democracy, and development in Latin America. In: Center for Strategic and International Studies, Policy Papers on the Americas, vol. XIV, study 6, 2003.

REVISTA VEJA. A conta vai para todos nós, 13 de junho de 2001.

. O insulfilm reduz a visão do interior do carro e atrapalha o ladrão, 13 de junho de 2001 .

RODRIK, Dani. Second-best institutions. American Economic Review, n. 88, p. 100-104, 2008.

SCHUARTZ, Luis Fernando Schuartz. Norma, contingência e racionalidade. Rio de Janeiro: Renovar, 2005.

SILVA, Virgílio Afonso da Silva. O proporcional e o razoável. Revista dos Tribunais, v. 91, n. 798, p. 23-50, 2002.

SOARES, Rodrigo R.; NARITOMI, Joana. Understanding high crime rates in Latin America: the role of social and policy factors. In: The economics of crime: lessons for and from Latin America. Chicago: University of Chicago Press, 2010.

SWEET, Alec Stone; MATHEWS, Jud. Proportionality balancing and global constitutionalism. Columbia Journal of Transnational Law, v. 47, p. 72-164, 2008.

TELLA, Rafael Di; EDWARDS, Sebastian; SCHARGRODSKY, Ernesto. Introduction. In: The economics of crime: lessons for and from Latin America. Chicago: University of Chicago Press, 2010.

TUSHNET, Mark. Defending Korematsu? In: TUSHNET, Mark (Ed.). The Constitution in wartime: beyond alarmism and complacency. Durham: Duke University Press, 2005.

VALOR ECONÔMICO. Empresas são contra abertura de salário, 7 de janeiro de 2009.

WALDRON, Jeremy. Safety and security. Nebraska Law Review, n. 85, p. 455-507, 2006. Security as a basic right (after 9/11). In: BEITZ, Charles; GOODIN, Robert (Eds.). Global basic rights. Oxford; New York: Oxford University Press, 2009. 
Praia de Botafogo, n. 190, sala 1304 Botafogo - 22250-040 Rio de Janeiro - RJ - Brasil diego.wernecklafgr.br

Rua Rocha, n. 233, sala 906 Bela Vista - 01330-000 São Paulo - SP - Brasil mariana.pargendlerlafgv.br
Diego Werneck Arguelhes

Professor PEsquisador da FGV Direito Rio Mestre em Direito Público e bacharel em Direito pela Universidade do Estado do Rio de Janeiro (UERJ) MASTER of LAWS (LL.M.) E DOUTORANDo (J.S.D.) PELA YALE LAW SCHOOL, EUA

\section{Mariana Pargendler}

Doutora E MESTRE EM DiREITO PELA YALE UniVERSity DOUTORA E BACHAREL EM DIREITO PELA Universidade Federal do RIO GRANDE do Sul Professora da Escola de Direito de São Paulo da Fundação Getulio Vargas (DIREITO GV) 
